\title{
PREPARATION AND EVALUATION OF 3,4"-ESTER DERIVATIVES OF 16-MEMBERED MACROLIDE ANTIBIOTICS RELATED TO TYLOSIN
}

\author{
H. A. Kirst, M. Debono, K. E. Willard, B. A. Truedell, J. E. Toth, \\ J. R. Turner, D. R. Berry, B. B. Briggs, D. S. FukudA, \\ V. M. Daupert, A. M. Felty-Duckworth, \\ J. L. OtT and F. T. COUNTER
}

The Lilly Research Laboratories, Eli Lilly and Company, Indianapolis, Indiana 46285, U.S.A.

(Received for publication August 4, 1986)

\begin{abstract}
A large group of ester derivatives of tylosin-related macrolides was prepared in which the hydroxyl groups at C-3 and C-4" were acylated by either chemical or biochemical methods. Most of the derivatives exhibited excellent in vitro antimicrobial activity. However, only the 3,4"-diacyl derivatives of tylosin and macrocin showed any significant improvements of in vivo efficacy against experimental infections in rodents.
\end{abstract}

Several macrolide antibiotics related to tylosin have now been reported which differ only in the degree of oxidation of, or the substituent attached to, C-23 of the lactone ring ${ }^{1,2)}$. Macrocin and $2^{\prime \prime \prime}$ - $O$-demethylmacrocin (DOMM) differ from tylosin in the degree of $O$-methylation of the neutral sugar mycinose while 23-demycinosyltylosin (DMT) and 23-de(mycinosyloxy)tylosin (DMOT) completely lack the saccharide moiety at this position (see Fig. 1). These latter two macrolides differ in the degree of oxidation of C-23. Hydrolysis of the terminal neutral sugar mycarose from each of these macrolides is readily accomplished under mildly acidic conditions, yielding a corresponding series of demycarosyl derivatives (see Fig. 1).

Esterification of the 3 and 4 "-hydroxyl groups of tylosin has been reported to yield derivatives which have improved antimicrobial activity against tylosin-resistant organisms and give higher blood levels of antibiotic after oral administration ${ }^{3,4)}$. However, it was uncertain whether analogous derivatives of the newly-available group of tylosin-related macrolides would exhibit any improvement in antimicrobial activity, especially in vivo after oral administration. In this paper, we report the preparation, antimicrobial evaluation and structure-activity relationships of the 3 and 4 "- $O$-acyl derivatives of macrocin, DOMM, DMT, DMOT and tylosin and the corresponding 3- $O$-acyl derivatives of the demycarosyl analogs lactenocin, 3"-O-demethyllactenocin (DOML), 5-O-mycaminosyltylonolide (OMT), 23-deoxy-5-O-mycaminosyltylonolide (DOMT) and desmycosin. Preparation of these esters utilized both chemical and bioconversion methods.

\section{Results and Discussion}

\section{Chemical Acylation}

The synthesis of 3 and $4^{\prime \prime}$-esters of DMT and DMOT by chemical procedures required prior derivatization of the $2^{\prime}$ and 23-hydroxyl groups of DMT or the $2^{\prime}$-hydroxyl group of DMOT. The synthesis of such $2^{\prime}$ and 23-ester derivatives of DMT and DMOT has already been reported ${ }^{5)}$. Once 
Fig. 1. Structure of tylosin and related 16-membered macrolides.

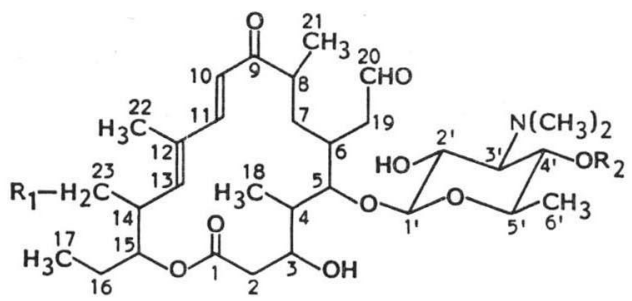

DOMT

$\mathrm{R}_{1}=\mathrm{H}$

$$
R_{2}=H
$$

DMOT

$R_{1}=H$

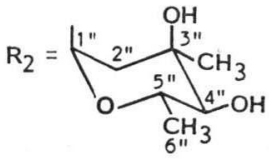

OMT

$\mathrm{R}_{1}=\mathrm{OH}$

$R_{2}=H$

DMT

$\mathrm{R}_{1}=\mathrm{OH}$

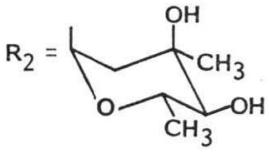

DOML

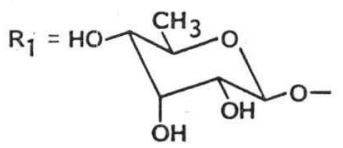

$\mathrm{R}_{2}=\mathrm{H}$

DOMM
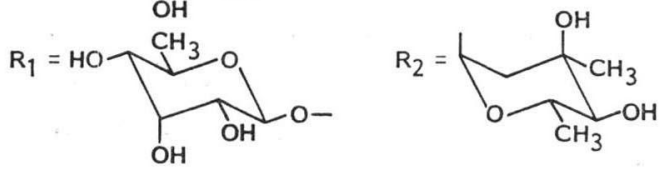

Lactenocin

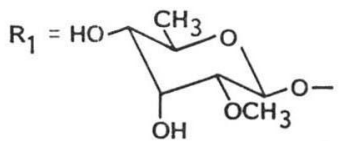

$\mathrm{R}_{2}=\mathrm{H}$

Macrocin
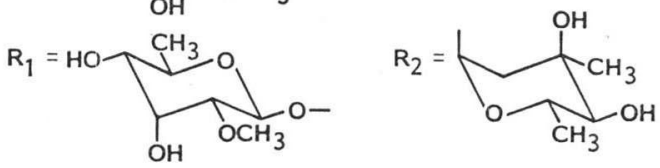

Desmycosin

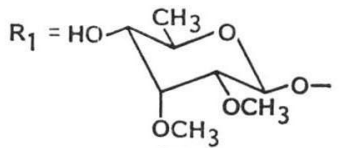

$\mathrm{R}_{2}=\mathrm{H}$

Tylosin
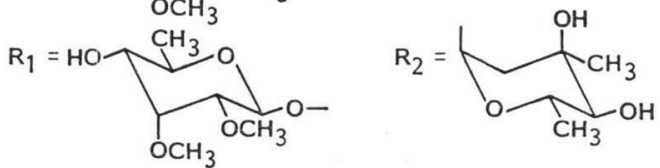

the hydroxyl groups at $2^{\prime}$ and 23 had been protected, the $4^{\prime \prime}$-hydroxyl group (on mycarose) in DMT and DMOT was the hydroxyl group most readily acylated. Complete selectivity was not always achieved, however. In some cases, the hydroxyl group at C-3 of the lactone ring was acylated only slightly less rapidly than the $4^{\prime \prime}$-hydroxyl group, so that mixtures of $4^{\prime \prime}$-mono- and $3,4^{\prime \prime}$-di- $O$-acyl 
derivatives were obtained; these were usually separated readily by standard chromatographic procedures. On the other hand, acylation of the 4"-hydroxyl group has been observed as a minor side reaction under some conditions during the acylation of the more reactive 23-hydroxyl group of $2^{\prime}-O$ acetyl-DMT. Thus, while the order of reactivity toward acylation follows the general pattern $23>$ $4^{\prime \prime}>3$, the differences in reactivity were not always sufficient to prevent mixtures of derivatives from being formed during acylation. Further work on the optimization of reaction conditions will be necessary in order to achieve both greater selectivity and higher overall yields in these acylation reactions. Removal of the 2'-O-acetyl protecting group from all of these acyl derivatives was easily achieved under standard methanolysis condition $\mathrm{s}^{5)}$.

The synthesis of a $4^{\prime \prime}$-O-monoacyl derivative of DMT required protection of the 23-hydroxyl group prior to acylation of the 4 "-hydroxyl group. The trichloroacetyl group was a useful protecting group for this purpose. It was readily attached to the $\mathrm{C}-23$ hydroxyl group and easily removed during reflux in aqueous methanol, conditions which did not hydrolyze the $4^{\prime \prime}-O$-acyl moiety. Similar procedures have been reported for the synthesis of $4^{\prime \prime}$ - $O$-acyl derivatives of tylosin ${ }^{4)}$. Only a single 3,4"acyl derivative of DMT has been previously mentioned in a brief communication on an attempted conversion of tylosin to $\mathrm{DMT}^{8)}$.

\section{Biochemical Acylation}

In contrast to tylosin, members of the leucomycin-carbomycin family of 16-membered macrolides are isolated from fermentations with their 3- and 4"-hydroxyl groups acylated by short chain fatty $\operatorname{acids}^{7)}$. Tylosin has been demonstrated to be an acceptable substrate for the enzymes responsible for acylation of the 3- and 4"-hydroxyl groups, permitting microbial transformation of tylosin to its analogous ester derivatives ${ }^{8)}$. As previously implied ${ }^{8)}$, such transformations are best performed with a mutant strain which has lost its ability to synthesize its natural macrolide antibiotic rather than with a wild-type strain. Use of the latter type produces mixtures of parent and transformed macrolides, resulting in tedious and difficult chromatographic separations. Use of mutant strains is also much preferred over use of the fatty acid biosynthesis inhibitor cerulenin to block the endogenous formation of wild-type macrolides ${ }^{9,10)}$.

A strain of Streptomyces thermotolerans, mutated to eliminate formation of its parent antibiotic carbomycin, was found to successfully bioconvert all of the tylosin-related macrolides-macrocin, DOMM, DMT and DMOT as well as tylosin itself. Modification or removal of the neutral sugar at C-23 did not affect the bioconversion process; the substituents on the lactone ring at C-23 are most likely so far removed from the active sites on the enzymes that modifications at this position cause no interference with the enzymatic steps. In each case, biochemical transformations afforded the desired ester derivatives directly without the need for the intermediate protection and deprotection steps required of the chemical methods.

The mixtures of acyl derivatives formed from each of the tylosin-related macrolides were separated and purified by HPLC techniques. These were all new compounds except for one derivative of DMT, which had previously been found after feeding tylactone to a strain of $S$. thermotolerans ${ }^{11)}$. The neutral sugar mycarose was readily hydrolyzed under mildly acidic conditions ${ }^{12)}$, yielding the corresponding series of 3-O-acyl derivatives of desmycosin, lactenocin, DOML, OMT and DOMT. The combination of these new compounds obtained from biochemical methods elegantly complemented those obtained from chemical methods to permit a thorough study of structure-activity relationships 
Table 1. Selected proton chemical shifts for ester derivatives ${ }^{a}$.

\begin{tabular}{llllll}
\hline \multicolumn{1}{c}{ Compound $^{\mathrm{b}}$} & \multicolumn{1}{c}{$2^{\prime}$} & \multicolumn{1}{c}{$4^{\prime}$} & \multicolumn{1}{c}{23} & \multicolumn{1}{c}{3} & $4^{\prime \prime}$ \\
\hline DMOT & 3.54 & 3.26 & 1.08 & 3.84 & 2.95 \\
3-Ac-4"-i Val-DMOT & 3.5 & 3.29 & 1.06 & 5.17 & 4.62 \\
DMT & 3.56 & 3.30 & 3.77 & 3.86 & 2.96 \\
2'-Ac-23-PhOAc-DMT & 5.01 & 3.3 & 4.16 & 3.8 & 2.95 \\
2'-Ac-3,23-di-PhOAc-DMT & 5.01 & 3.28 & 4.15 & 5.22 & 2.96 \\
2'-Ac-4", 23-di-PhOAc-DMT & 5.01 & 3.28 & 4.1 & 3.8 & 4.7 \\
Macrocin & 3.51 & 3.26 & $4.02 / 3.54$ & 3.82 & 2.95 \\
3-Ac-macrocin & 3.5 & 3.26 & $3.99 / 3.5$ & 5.16 & 3.0 \\
3-Ac-4"-Bu-macrocin & 3.5 & 3.28 & $3.98 / 3.5$ & 5.16 & 4.62 \\
3-Ac-4"- $i$ Val-macrocin & 3.5 & 3.28 & $3.99 / 3.5$ & 5.16 & 4.63 \\
Lactenocin & 3.48 & 3.06 & $4.02 / 3.54$ & 3.84 & - \\
3-Ac-lactenocin & 3.5 & 3.04 & $3.99 / 3.5$ & 5.17 & - \\
\hline
\end{tabular}

a Chemical shift values in $\delta$ (ppm from internal TMS); deuteriochloroform solvent.

b Abbreviations: Ac; Acetyl, iVal; iso-valeryl, PhOAc; phenoxyacetyl, Bu; butyryl.

with 3- and 4"-O-acyl derivatives of tylosin-related macrolides.

\section{Elucidation of Structure of Esters}

The structures of the 3- and 4"-acyl derivatives were assigned principally by the combination of mass spectrometry and UV and ${ }^{1} \mathrm{H}$ NMR spectroscopy. By field desorption mass spectrometry (FD-MS), the parent ion $\left(m / z=\mathrm{MW}+\mathrm{H}^{+}\right)$of each derivative was readily obtained, thereby providing the molecular weight and a strong indication of the composition of each derivative isolated from the acylation processes. The intact presence of the dienone chromophore was confirmed by the UV spectrum. The structures were then firmly established by their ${ }^{1} \mathrm{H}$ NMR spectra. The most characteristic proton chemical shifts of a representative group of acyl derivatives are presented in Table 1, exemplifying the downfield shifts of the appropriate proton resonances after acylation.

\section{In Vitro Activity}

Acylation of the $4^{\prime \prime}$-hydroxyl group of DMT and its derivatives did not generally cause major alterations of in vitro antimicrobial activity. Acylation of the 4"-hydroxyl group by an acetyl, propionyl or isovaleryl group altered the activity only slightly, in either direction, whereas acylation by larger moieties such as phenylacetyl or phenoxyacetyl often diminished the activity, occasionally by several-fold (see Table 2). Acylation of the 4"-hydroxyl group of DMOT showed a similar trend for in vitro activity (see Table 3). Acylation of either the 3-hydroxyl group or both the 3- and 4"-hydroxyl groups of several macrolides resulted in only minor changes of in vitro activity (see Tables $2 \sim 4)$. These results are in general agreement with conclusions reported for a series of acyl derivatives of tylosin ${ }^{3,4)}$. The present study demonstrated that in vitro antibiotic activity was well retained with 4 " - and/or 3-esters of tylosin-related macrolides and provided samples for in vivo evaluation to determine if oral efficacy or bioavailability was improved for these types of modifications.

\section{In Vivo Activity}

Initial testing for in vivo antibiotic activity was performed with an experimental infection in mice induced by Streptococcus pyogenes C203. As reported in Table 5, this infection was readily treated orally by erythromycin and josamycin, the two macrolide antibiotics most widely used in clinical practice. Disappointingly, none of the acyl derivatives of DMT or DMOT, including the parent 
Table 2. In vitro activity of ester derivatives of DMT.

\begin{tabular}{|c|c|c|c|c|c|}
\hline \multirow[b]{2}{*}{ Ester of DMT } & \multicolumn{5}{|c|}{$\operatorname{MIC}(\mu \mathrm{g} / \mathrm{ml})$} \\
\hline & $\underset{\mathrm{X} 1}{S .}$. & $\begin{array}{l}\text { S.e. } \\
\text { EPI } 1\end{array}$ & $\begin{array}{l}\text { S. py. } \\
\text { C203 }\end{array}$ & $\begin{array}{l}\text { S. pn. } \\
\text { Park I }\end{array}$ & $\begin{array}{l}\text { S. } f . \\
\times 66\end{array}$ \\
\hline DMT & 1 & 1 & 0.25 & 0.5 & 1 \\
\hline $2^{\prime}, 23,4^{\prime \prime}$-tri-Ac & 1 & 1 & 0.5 & 0.12 & 1 \\
\hline $2^{\prime}-\mathrm{Ac}-23,4^{\prime \prime}-\mathrm{di}-\mathrm{Pr}$ & 0.5 & 0.5 & 0.12 & 0.03 & 0.5 \\
\hline $2^{\prime}-\mathrm{Ac}-23,4^{\prime \prime}-\mathrm{di}-\mathrm{TCA}$ & 4 & 2 & 2 & 0.25 & 4 \\
\hline $2^{\prime}-\mathrm{Ac}-23,4^{\prime \prime}$-di-PhAc & 8 & 8 & 0.25 & 0.25 & 8 \\
\hline $2^{\prime}-\mathrm{Ac}-23,4^{\prime \prime}$-di-PhOAc & 16 & 16 & 4 & 2 & 16 \\
\hline $2^{\prime}-\mathrm{Ac}-23-\mathrm{TCA}-4^{\prime \prime}-\mathrm{Pr}$ & 0.5 & 0.5 & 0.5 & 0.12 & 2 \\
\hline $23,4^{\prime \prime}-\mathrm{di}-\mathrm{Ac}$ & 0.5 & 1 & 0.25 & 0.12 & 0.5 \\
\hline $23,4^{\prime \prime}$-di-Pr & 0.5 & 0.5 & 0.25 & 0.06 & 1 \\
\hline $23,4^{\prime \prime}-$ di-PhAc & 1 & 1 & 0.25 & 0.12 & 0.5 \\
\hline $2^{\prime}$-Ac-3,23-di-PhOAc & 0.5 & 1 & 0.12 & 0.12 & 0.5 \\
\hline $2^{\prime}-\mathrm{Ac}-3,23-\mathrm{di}-\mathrm{TCA}$ & 1 & 1 & 0.5 & 0.12 & 2 \\
\hline $2^{\prime}-\mathrm{Ac}-3,23,4^{\prime \prime}-\operatorname{tri}-\mathrm{Pr}$ & 1 & 1 & 0.5 & 0.25 & 1 \\
\hline $2^{\prime}-\mathrm{Ac}-3,23,4^{\prime \prime}$-tri-TCA & 8 & 8 & 8 & 2 & 16 \\
\hline $2^{\prime}-\mathrm{Ac}-23-\mathrm{TCA}-3,4^{\prime \prime}-$ di- $\mathrm{Pr}$ & 0.5 & 0.5 & 0.5 & 0.06 & 2 \\
\hline $3,23,4^{\prime \prime}-\operatorname{tri}-\mathrm{Pr}$ & 0.5 & 1 & 0.25 & 0.12 & 1 \\
\hline $3,4^{\prime \prime}$-di-Pr & 0.5 & 0.5 & 0.25 & 0.06 & 1 \\
\hline $3-\mathrm{Ac}-4^{\prime \prime}-i \mathrm{Val}$ & 0.5 & 1 & 0.25 & 0.06 & 1 \\
\hline $3-\mathrm{Ac}-4^{\prime \prime}-\mathrm{Bu}$ & 0.5 & 0.5 & 0.25 & 0.06 & 1 \\
\hline 3-Ac & 2 & 2 & 1 & 1 & 4 \\
\hline $3-\mathrm{Pr}$ & 1 & 1 & 0.5 & 0.25 & 2 \\
\hline $4^{\prime \prime}-\mathrm{Pr}$ & 0.5 & 0.5 & 0.12 & 0.06 & 0.5 \\
\hline
\end{tabular}

Organisms: S.a.; Staphylococcus aureus, S.e.; Staphylococcus epidermidis, S.py.; Streptococcus pyogenes, S.pn.; Streptococcus pneumoniae, S.f.; Streptococcus faecalis, all organisms were taken from the Lilly culture collection.

Abbreviations: Ac; Acetyl, Pr; propionyl, TCA; trichloroacetyl, PhAc; phenylacetyl, PhOAc; phenoxyacetyl, $i$ Val; iso-valeryl, Bu; butyryl.

Table 3. In vitro activity of ester derivatives of DMOT.

\begin{tabular}{|c|c|c|c|c|c|}
\hline \multirow{2}{*}{$\begin{array}{l}\text { Ester of } \\
\text { DMOT }\end{array}$} & \multicolumn{5}{|c|}{$\mathrm{MIC}(\mu \mathrm{g} / \mathrm{ml})$} \\
\hline & $\underset{\mathrm{X} 1}{S .}$ & $\begin{array}{l}\text { S.e. } \\
\text { EPI } 1\end{array}$ & $\begin{array}{l}\text { S. py. } \\
\text { C203 }\end{array}$ & $\begin{array}{l}\text { S. pn. } \\
\text { Park I }\end{array}$ & $\begin{array}{l}S . f . \\
\text { X } 66\end{array}$ \\
\hline DMOT & 0.5 & 0.5 & 0.25 & 0.12 & 0.5 \\
\hline $2^{\prime}-\mathrm{Ac}$ & 0.5 & 0.5 & 0.25 & 0.12 & 1 \\
\hline $2^{\prime}-\mathrm{Ac}-4^{\prime \prime}-\mathrm{Pr}$ & 0.25 & 0.5 & 0.25 & 0.12 & 0.5 \\
\hline $2^{\prime}-\mathrm{Ac}-4^{\prime \prime}-i \mathrm{Val}$ & 1 & 1 & 0.5 & 0.06 & 1 \\
\hline $4^{\prime \prime}-\operatorname{Pr}$ & 0.5 & 0.5 & 0.5 & 0.12 & 1 \\
\hline $4^{\prime \prime}-i \mathrm{Val}$ & 1 & 1 & 0.25 & 0.03 & 1 \\
\hline $4^{\prime \prime}-\mathrm{PhAc}$ & 16 & 16 & 8 & 8 & 16 \\
\hline $2^{\prime}-\mathrm{Ac}-3,4^{\prime \prime}-\mathrm{di}-\mathrm{Pr}$ & 0.5 & 0.5 & 0.5 & 0.06 & 1 \\
\hline $3,4^{\prime \prime}$-di-Pr & 0.5 & 1 & 0.5 & 0.25 & 1 \\
\hline $3,4^{\prime \prime}-$ di-Ac & 1 & 1 & 0.25 & 0.5 & 1 \\
\hline $3-\mathrm{Ac}-4^{\prime \prime}-i \mathrm{Val}$ & 1 & 1 & 0.5 & 0.06 & 1 \\
\hline $3-A c-4^{\prime \prime}-B u$ & 0.5 & 1 & 0.5 & 0.06 & 1 \\
\hline 3-Ac & 1 & 1 & 0.5 & 0.12 & 2 \\
\hline
\end{tabular}

Abbreviations: See Table 2 .

compounds, treated this infection orally. Furthermore, none of these acyl derivatives treated parenterally as well as DMT itself (see Table 5). In contrast to results reported for tylosin ${ }^{3,4)}$ and confirmed in our study, improvement of oral antibiotic activity was not observed for the closely-related 
Table 4. In vitro activity of 3 and/or $4^{\prime \prime}$-ester derivatives.

\begin{tabular}{|c|c|c|c|c|c|}
\hline \multirow{2}{*}{ Compound } & \multicolumn{5}{|c|}{$\operatorname{MIC}(\mu \mathrm{g} / \mathrm{ml})$} \\
\hline & $\begin{array}{l}\text { S. } a \text {. } \\
\mathrm{X} 1\end{array}$ & $\begin{array}{l}\text { S.e. } \\
\text { EPI } 1\end{array}$ & $\begin{array}{l}\text { S. py. } \\
\text { C203 }\end{array}$ & $\begin{array}{l}\text { S. pn. } \\
\text { Park I }\end{array}$ & $\begin{array}{l}S . f . \\
\mathrm{X} 66\end{array}$ \\
\hline Tylosin & 0.5 & 1 & 0.25 & 0.25 & 2 \\
\hline 3-Ac-4" $-i \mathrm{Val}$ & 1 & 2 & 0.5 & 0.25 & 2 \\
\hline $3-\mathrm{Ac}-4^{\prime \prime}-\mathrm{Bu}$ & 1 & 2 & 0.5 & 0.25 & 2 \\
\hline $3-A c$ & 0.5 & 1 & 0.25 & 0.25 & 2 \\
\hline Macrocin & 0.5 & 1 & 0.25 & 0.12 & 2 \\
\hline $3-\mathrm{Ac}-4^{\prime \prime}-i \mathrm{Val}$ & 1 & 1 & 0.25 & 0.25 & 2 \\
\hline $3-\mathrm{Ac}-4^{\prime \prime}-\mathrm{Bu}$ & 1 & 1 & 0.5 & 0.25 & 2 \\
\hline $3-A c$ & 0.5 & 0.5 & 0.25 & 0.5 & 2 \\
\hline DOMM & 8 & 4 & 0.5 & 0.25 & 16 \\
\hline 3-Ac-4"-iVal & 2 & 1 & 0.12 & 0.12 & 4 \\
\hline $3-\mathrm{Ac}-4^{\prime \prime}-\mathrm{Bu}$ & 4 & 1 & 0.12 & 0.12 & 8 \\
\hline $3-\mathrm{Ac}$ & 2 & 2 & 0.25 & 0.25 & 8 \\
\hline Desmycosin & 1 & 1 & 0.25 & 0.25 & 2 \\
\hline 3-Ac & 0.5 & 0.5 & 0.12 & 0.5 & 2 \\
\hline Lactenocin & 2 & 2 & 0.5 & 0.5 & 4 \\
\hline $3-\mathrm{Ac}$ & 1 & 1 & 0.25 & 0.5 & 8 \\
\hline DOML & 4 & 4 & 1 & 1 & 16 \\
\hline $3-A c$ & 4 & 4 & 1 & 1 & 16 \\
\hline OMT & 1 & 1 & 0.5 & 0.25 & 1 \\
\hline $3-A c$ & 1 & 1 & 1 & 2 & 2 \\
\hline 3-Pr & 0.5 & 0.5 & 0.5 & 0.25 & 1 \\
\hline 3,23-di-Ac & 0.5 & 0.5 & 0.25 & 0.25 & 0.5 \\
\hline DOMT & 0.25 & 0.25 & 0.25 & 0.25 & 0.5 \\
\hline $3-\mathrm{Ac}$ & 0.5 & 0.5 & 0.5 & 0.25 & 1 \\
\hline
\end{tabular}

Abbreviations: See Table 2.

macrolides DMT and DMOT. This was particularly unexpected since DMT and DMOT lack the saccharide moiety at C-23 and thus appear more structurally related to leucomycin, josamycin and carbomycin than does tylosin.

The previously reported increased oral efficacy of acyl derivatives of tylosin was confirmed in the present investigation (see Table 6). Unlike the DMT and DMOT series, the analogous derivatives of macrocin showed increased oral efficacy in this infection model. This improvement appeared to result from the $4^{\prime \prime}$-acylation since 3-O-acetylation alone resulted in no change of oral $\mathrm{ED}_{50}$ value. The important role of mycarose was also evident in that none of the demycarosyl derivatives had significant oral efficacy even though they demonstrated good parenteral efficacy. These results clearly indicate that factors beside 3- and $44^{\prime \prime}$ - $O$-acyl modifications, such as the two neutral sugars and the nature of substitution of the lactone ring, are required to confer oral antibiotic activity on macrolide structures.

Peripheral plasma levels were also measured for a number of selected acyl derivatives following oral administration to mice of a $100 \mathrm{mg} / \mathrm{kg}$ dose. This relatively large dose was selected because many of the $\mathrm{ED}_{50}$ values were near or above $100 \mathrm{mg} / \mathrm{kg}$. Despite this high dose, the plasma levels measured were relatively low and short-lived (see Table 7). Even those acyl derivatives which showed better oral efficacy than tylosin against experimental infections in mice failed to give better blood levels in that animal species. However, since tylosin itself gives low blood levels, the same pharmacokinetic profile that concentrates tylosin and other macrolides in tissues such as lung rather than 
Table 5. In vivo activity of 3 and/or 4"-ester derivatives of DMT and DMOT against infections experimentally induced by Streptococcus pyogenes C203 in mice.

\begin{tabular}{|c|c|c|}
\hline \multirow{2}{*}{ Compound } & \multicolumn{2}{|c|}{$\mathrm{ED}_{50}(\mathrm{mg} / \mathrm{kg} \times 2)$} \\
\hline & sc & po \\
\hline DMOT & 5.7 & 78 \\
\hline $3-\mathrm{Ac}-4^{\prime \prime}-i \mathrm{Val}$ & 6.2 & $>50$ \\
\hline $3-\mathrm{Ac}-4^{\prime \prime}-\mathrm{Bu}$ & $>6.2$ & $>50$ \\
\hline $3,4^{\prime \prime}-$ di- $P r$ & $>10$ & $>100$ \\
\hline 3-Ac & $>6.2$ & $>50$ \\
\hline $4^{\prime \prime}-\operatorname{Pr}$ & 21.7 & 71 \\
\hline$\underline{\mathrm{DMT}}$ & 1.9 & 82 \\
\hline $3-\mathrm{Ac}-4^{\prime \prime}-i \mathrm{Val}$ & 3.9 & 100 \\
\hline $3-\mathrm{Ac}-4^{\prime \prime}-\mathrm{Bu}$ & 6.2 & $>100$ \\
\hline $3,4^{\prime \prime}-$ di-Pr & $>10$ & $>80$ \\
\hline 3-Ac & 12.5 & $>100$ \\
\hline $4^{\prime \prime}-\mathrm{Pr}$ & $>10$ & $>94$ \\
\hline $23,4^{\prime \prime}$-di-Pr & 12 & $>150$ \\
\hline $23,4^{\prime \prime}$-di-Ac & 7.7 & 117 \\
\hline 23,4"-di-PhAc & $>20$ & $>150$ \\
\hline $2^{\prime}, 23,4^{\prime \prime}$-tri-Ac & $>10$ & 179 \\
\hline $3,23,4^{\prime \prime}$-tri-Pr & 13.5 & $>150$ \\
\hline OMT & 2.6 & 97 \\
\hline $3-A c$ & 13.6 & $>100$ \\
\hline 3,23-di-Ac & 4.1 & $>100$ \\
\hline Josamycin & 7.6 & 35 \\
\hline Erythromycin & 0.9 & 10 \\
\hline
\end{tabular}

Abbreviations: See Table 2.

Table 6. In vivo activity of 3 and/or 4"'-ester derivatives related to tylosin against infections experimentally induced by Streptococcus pyogenes C203 in mice.

\begin{tabular}{lcc}
\hline \multirow{2}{*}{ Compound } & \multicolumn{2}{c}{$\mathrm{ED}_{50}(\mathrm{mg} / \mathrm{kg} \times 2)$} \\
\cline { 2 - 3 } & $\mathrm{sc}$ & po \\
\hline Tylosin & 0.7 & 33 \\
3-Ac-4"-iVal & 7.9 & 11 \\
3-Ac-4"'-Bu & 4.2 & 24 \\
3-Ac & 1.7 & 33 \\
Macrocin & 1.7 & 71 \\
3-Ac-4"'-iVal & 5.4 & 41 \\
3-Ac-4"'-Bu & 3.3 & 50 \\
3-Ac & 1.1 & 73 \\
Desmycosin & 0.8 & 80 \\
3-Ac & $<1.6$ & 70 \\
$\frac{\text { Lactenocin }}{3-A c}$ & 1.8 & 81 \\
\hline
\end{tabular}

Abbreviations: See Table 2.

in circulating plasma may also be at work for the acyl derivatives of tylosin ${ }^{13)}$. Consequently, measurement of peripheral plasma levels may not give the most relevant information regarding improvements in oral bioavailability.

\section{Conclusion}

By a combination of chemical and biochemical methodology, a large series of new 3 and $4 "$ - $O$-acyl derivatives of several 16-membered macrolide antibiotics related to tylosin were prepared. In vitro evaluation of these ester derivatives demonstrated good antibiotic activity against Gram-positive bacteria for most of the compounds. However, the majority of derivatives had poor antimicrobial efficacy in vivo against an experimental streptococcal infection in mice by both parenteral and oral routes of administration. Furthermore, circulating plasma levels were generally low and short-lived after oral dosing. Only the 3,4"-di-Oacyl derivatives of tylosin and macrocin appeared to possess any in vivo advantages over the parent antibiotics. Whether the advantages noted here are sufficient to warrant product development can only be ascertained by further studies.

\section{Experimental}

\section{Physico-chemical Determinations and Chromatography}

${ }^{1} \mathrm{H}$ NMR spectra were measured in $\mathrm{CDCl}_{3}$ solution on a Bruker WH-360 or Jeol FX90A NMR spectrometer. Field desorption mass spectra were obtained on a Varian-MAT 731 spectrometer using carbon dendrite emitters. UV spectra were measured in 95\% ethanol solution on a Cary 219 spectrometer. Thin-layer chromatography (TLC) was performed using E. Merck plates of silica gel 60 with a fluorescent indicator (F-254); visualization was effected by UV light. Product purification was carried out by chromatography on silica gel, using either flash chromatography techniques ${ }^{14)}$ with E. Merck grade 60 silica gel or a Waters Model 500 Prep LC system.

\section{In Vitro and In Vivo Evaluation}

Antibiotic susceptibility data given in Tables $2 \sim 4$ were obtained by agar dilution procedures as 
Table 7. Peripheral plasma levels $(\mu \mathrm{g} / \mathrm{ml})$ of ester derivatives of macrolides in mice following a $100 \mathrm{mg} / \mathrm{kg}$ oral dose.

\begin{tabular}{|c|c|c|c|c|c|}
\hline \multirow{2}{*}{ Compound } & \multicolumn{3}{|c|}{ Minutes } & \multicolumn{2}{|c|}{ Hour(s) } \\
\hline & 5 & 15 & 30 & 1 & 2 \\
\hline DMOT & 0.46 & 0.34 & 0.12 & 0.08 & $\mathrm{NZ}$ \\
\hline $3-\mathrm{Ac}-4^{\prime \prime}-i \mathrm{Val}$ & $\mathrm{NZ}$ & $\mathrm{NZ}$ & $\mathrm{NZ}$ & $\mathrm{NZ}$ & $\mathrm{NZ}$ \\
\hline$\underline{\mathrm{DMT}}$ & $\mathrm{NZ}$ & $\mathrm{NZ}$ & NZ & $\mathrm{NZ}$ & $\mathrm{NZ}$ \\
\hline $2^{\prime}-A c$ & 0.1 & 0.05 & 0.04 & 0.10 & 0.02 \\
\hline $2^{\prime}, 23$-di-Ac & 2.58 & 1.58 & 0.2 & 0.18 & 0.14 \\
\hline $23-\mathrm{Ac}$ & $\mathrm{NZ}$ & $\mathrm{NZ}$ & $\mathrm{NZ}$ & NZ & $\mathrm{NZ}$ \\
\hline $2^{\prime}, 23,4^{\prime \prime}$-tri-Ac & 1.83 & 1.08 & 0.75 & 0.51 & 0.47 \\
\hline $3-\mathrm{Ac}-4^{\prime \prime}-\mathrm{Bu}$ & NZ & $\mathrm{NZ}$ & NZ & $\mathrm{NZ}$ & NZ \\
\hline $3-\mathrm{Ac}-4^{\prime \prime}-i \mathrm{Val}$ & $\mathrm{NZ}$ & $\mathrm{NZ}$ & $\mathrm{NZ}$ & $\mathrm{NZ}$ & $\mathrm{NZ}$ \\
\hline OMT & 0.63 & 1.68 & $\mathrm{NZ}$ & $\mathrm{NZ}$ & NZ \\
\hline 23-Ac & 0.51 & 1.31 & 0.42 & $\mathrm{NZ}$ & $\mathrm{NZ}$ \\
\hline 3,23-di-Ac & $\mathrm{NZ}$ & $\mathrm{NZ}$ & $\mathrm{NZ}$ & $\mathrm{NZ}$ & $\mathrm{NZ}$ \\
\hline Tylosin & 1.29 & $\mathrm{NZ}$ & $\mathrm{NZ}$ & $\mathrm{NZ}$ & NZ \\
\hline $3-\mathrm{Ac}-4^{\prime \prime}-i \mathrm{Val}$ & $\mathrm{NZ}$ & $\mathrm{NZ}$ & $\mathrm{NZ}$ & $\mathrm{NZ}$ & 0.02 \\
\hline Macrocin & $\mathrm{NZ}$ & 0.5 & $\mathrm{NZ}$ & $\mathrm{NZ}$ & $\mathrm{NZ}$ \\
\hline $3-\mathrm{Ac}-4^{\prime \prime}-i \mathrm{Val}$ & $\mathrm{NZ}$ & $\mathrm{NZ}$ & $\mathrm{NZ}$ & 0.25 & $\mathrm{NZ}$ \\
\hline$\underline{\text { DOMM }}$ & $\mathrm{NZ}$ & $\mathrm{NZ}$ & $\mathrm{NZ}$ & $\mathrm{NZ}$ & $\mathrm{NZ}$ \\
\hline $3-\mathrm{Ac}-4^{\prime \prime}-\mathrm{Bu}$ & $\mathrm{NZ}$ & $\mathrm{NZ}$ & $\mathrm{NZ}$ & $\mathrm{NZ}$ & NZ \\
\hline
\end{tabular}

* NZ: No zone on assay plates seeded with Micrococcus luteus.

Abbreviations: See Table 2.

previously described ${ }^{15)}$. Mouse protection experiments were conducted by treating infected animals 1 and 5 hours post-infection with either subcutaneous or oral administration of $0.25 \mathrm{ml}$ of a $10 \%$ aq ethanol solution of the antibiotic over a range of concentrations. Peripheral plasma levels were determined by microbiological assay using Micrococcus luteus; concentrations represent average values from 5 mice per time period.

\section{Isolation of Mutant NRRL 15270}

Streptomyces thermotolerans, strain ATCC 11416, was treated with $N$-methyl- $N$ '-nitro- $N$-nitrosoguanidine (NTG) according to the procedure of BALTZ and $\mathrm{SENO}^{18)}$. Aliquots of the cell suspension, after NTG treatment, were plated on BENNETT's agar medium to recover survivors. Approximately 200 cultures were isolated which did not produce detectable amounts of the parental antibiotic, carbomycin. To assess their ability to synthesize the 3 and 4 " esters of tylosin and its intermediates, isolates were cultured in CSI broth medium (glucose $2.5 \%$, soybean grits $1.5 \%$, blackstrap molasses $0.3 \%$, Amber EHA-enzyme hydrolyzed casein $0.1 \%, \mathrm{CaCO}_{3} 0.25 \%$, CZAPEK's mineral stock $2.0 \mathrm{ml} /$ liter), to which $0.5 \mathrm{mg} / \mathrm{ml}$ substrate was added after 24 hours growth. Ester synthesis was assayed by visual estimation of the amount of ester found after thin-layer chromatography of ethyl acetate extracts from these cultures. Identification of the esters and quantification of ester synthesis was confirmed by HPLC analysis of these extracts. Strain NRRL 15270, selected by this procedure, was found to synthesize approximately eight times as much 3-acetyl-4"-isovaleryl or 3-acetyl-4"-butyryl esters of tylosin and macrocin as the parental strain, ATCC 11416.

\section{Biosynthesis of Esters}

Small scale fermentations were carried out in 250-ml Erlenmeyer flasks containing $50 \mathrm{ml}$ broth medium and large scale fermentations were carried out in 25 -liter stirred vessels. The culture medium used in both cases was CSI. Vegetative inoculum for fermentations was a 24-hour culture of NRRL 15270 in CSI medium. Inoculum for small and large fermentations was $0.4 \%$ and $0.8 \%$, respectively, of the vegetative culture. Fermentation cultures were incubated, with stirring at $37^{\circ} \mathrm{C}$, for $22 \sim 24$ hours, at which time macrolide substrates (final concentration $0.5 \mathrm{mg} / \mathrm{ml}$ ) and DL-norvaline or L-leucine (final concentration $2.0 \mathrm{mg} / \mathrm{ml}$ ) were added. Cultures were monitored for ester synthesis 
by HPLC analysis. Synthesis of the diesters was generally complete within 10 to 16 hours after substrate addition, with the 3-O-acetyl ester being formed first and the 4 "'-O-isovaleryl or butyryl ester being formed later. At harvest, the broth was adjusted to $\mathrm{pH} 8.5$ and extracted twice with equal volumes of ethyl acetate. Extracts were combined and concentrated under vacuum, and products were isolated by reverse-phase HPLC. HPLC systems used for assay and isolation were Waters $\mu$ Bondapak C-18 or Merck Li-Chrosorb RP-18 adsorbents with water - methanol - ammonium formate $(40: 60: 0.2)$ for the $3-O$-acetyl esters and the same solvents in a different ratio $(25: 75: 0.2)$ for the diesters.

\section{2'-O-Acetyl-DMOT}

DMOT $(5.0 \mathrm{~g}, 6.7 \mathrm{mmol})$ was dissolved in acetone $(150 \mathrm{ml})$ and treated with acetic anhydride $(0.84 \mathrm{ml}, 8.2 \mathrm{mmol})$ dropwise with stirring at room temp. After stirring for 17 hours, solvent was evaporated under reduced pressure. The residue was dissolved in a small volume of ethyl acetate and chromatographed, eluting with ethyl acetate.

Fractions containing the desired product were combined and evaporated to dryness to yield $4.2 \mathrm{~g}$ $(80 \%)$ of 2'-O-acetyl-DMOT; FD-MS $767\left(\mathrm{M}^{+}\right)$; UV $\lambda_{\max } \mathrm{nm}(\varepsilon) 284$ (21,000); NMR $\delta 2.08$ (s, acetyl).

\section{2'-O-Acetyl-4" $O$-phenylacetyl-DMOT}

$2^{\prime}$-O-Acetyl-DMOT $(2.7 \mathrm{~g}, 3.5 \mathrm{mmol})$ was dissolved in dichloromethane $(70 \mathrm{ml})$ and pyridine $(0.8 \mathrm{ml})$ and treated with a solution of phenylacetyl chloride $(0.56 \mathrm{ml}, 3.5 \mathrm{mmol})$ in dichloromethane $(30 \mathrm{ml})$ dropwise with stirring at room temp. After the reaction had stirred for 6 hours, solvent was evaporated and the residue was dissolved in dichloromethane and extracted with saturated $\mathrm{NaHCO}_{3}$ solution. The organic layer was separated, dried $\left(\mathrm{Na}_{2} \mathrm{SO}_{4}\right)$, filtered and evaporated. The residue was dissolved in ethyl acetate and chromatographed, eluting with ethyl acetate. Fractions containing the desired product were combined and evaporated to dryness to yield $1.2 \mathrm{~g} \mathrm{(38 \% )}$ of 2'-O-acetyl-4"$O$-phenylacetyl-DMOT; FD-MS $886\left(\mathrm{M}+\mathrm{H}^{+}\right)$; UV $\lambda_{\max } \mathrm{nm}(\varepsilon) 279(17,300)$, end absorption; NMR $\delta 2.07$ (s, acetyl), 3.7 (s, $\left.\mathrm{CH}_{2} \mathrm{Ph}\right), 7.0 \sim 7.4$ (m, phenyl).

\section{2'-O-Acetyl-4"-O-propionyl- and 2'-O-Acetyl-3,4"'-di-O-propionyl-DMOT}

$2^{\prime}$-O-Acetyl-DMOT $(1.0 \mathrm{~g}, 1.3 \mathrm{mmol})$ was dissolved in pyridine $(30 \mathrm{ml})$ and treated with propionic anhydride $(0.6 \mathrm{ml}, 4.6 \mathrm{mmol})$ dropwise with stirring at room temp. After 20 hours, additional propionic anhydride $(3 \mathrm{ml}, 23 \mathrm{mmol}$ ) was added and the reaction was stirred for an additional 26 hours at room temp. The mixture was diluted with toluene $(30 \mathrm{ml})$ and evaporated under reduced pressure. The residual oil was dissolved in dichloromethane and extracted with saturated $\mathrm{NaHCO}_{3}$ solution; the organic layer was separated, dried $\left(\mathrm{Na}_{2} \mathrm{SO}_{4}\right)$, filtered and evaporated. The residue was chromatographed on silica gel, eluting with a linear gradient of toluene and ethyl acetate. 2'-O-Acetyl-3,4'di- $O$-propionyl-DMOT $\left(305 \mathrm{mg}\right.$ ) was eluted first; FD-MS $879\left(\mathrm{M}^{+}\right)$; UV $\lambda_{\max } \mathrm{nm}(\varepsilon) 282(24,500)$; followed by $2^{\prime}-O$-acetyl-4"-O-propionyl-DMOT $(286 \mathrm{mg})$; FD-MS $823\left(\mathrm{M}^{+}\right)$; UV $\lambda_{\max } \mathrm{nm}(\varepsilon) 284$ $(24,200)$.

\section{4"-O-Phenylacetyl-DMOT}

2'-O-Acetyl-4" $O$-phenylacetyl-DMOT $(0.2 \mathrm{~g}, 0.23 \mathrm{mmol})$ was dissolved in $80 \%$ aq methanol $(18 \mathrm{ml})$ and refluxed for 5 hours. The solution was cooled to room temp and evaporated to dryness to yield $0.16 \mathrm{~g}(86 \%)$ of $4^{\prime \prime}-O$-phenylacetyl-DMOT; FD-MS $844\left(\mathrm{M}+\mathrm{H}^{+}\right)$; UV $\lambda_{\max } \mathrm{nm}(\varepsilon) 278(16,300)$, end absorption; NMR $\delta 3.7$ (s, $\left.\mathrm{CH}_{2} \mathrm{Ph}\right), 7.0 \sim 7.2$ (m, phenyl).

\section{2',23,4"'-Tri-O-acetyl-DMT}

DMT (10.0 g, $13.5 \mathrm{mmol})$ was dissolved in pyridine $(150 \mathrm{ml})$ and treated with acetic anhydride $(5.8 \mathrm{ml}, 60.7 \mathrm{mmol})$ with stirring at room temp. After the reaction had stirred overnight, solvent was evaporated under reduced pressure. The residual oil was dissolved in dichloromethane and extracted with saturated $\mathrm{NaHCO}_{3}$ solution. The organic layer was separated, dried $\left(\mathrm{Na}_{2} \mathrm{SO}_{4}\right)$, filtered and evaporated under reduced pressure. The residual material was purified by chromatography, eluting with a linear gradient of toluene - ethyl acetate (3:1) and ethyl acetate. Fractions containing the desired product were identified by TLC, combined and evaporated under reduced pressure to yield $4.5 \mathrm{~g}$ of 2',23,4"'-tri- $O$-acetyl-DMT; FD-MS $868\left(\mathrm{M}+\mathrm{H}^{+}\right)$; UV $\lambda_{\max } \mathrm{nm}(\varepsilon) 280(21,100)$; NMR $\delta 2.06$ (s, 
two acetyl), 2.09 (s, one acetyl).

2'-O-Acetyl-23-O-phenylacetyl- and 2'-O-Acetyl-23,4"-di- $O$-phenylacetyl-DMT

$2^{\prime}$ - $O$-Acetyl-DMT $(2.75 \mathrm{~g}, 3.5 \mathrm{mmol})$ was dissolved in dichloromethane $(75 \mathrm{ml})$ and pyridine $(0.8 \mathrm{ml})$ and treated with a solution of phenylacetyl chloride $(0.56 \mathrm{ml}, 3.5 \mathrm{mmol})$ in dichloromethane $(13 \mathrm{ml})$ dropwise with stirring at room temp. After 1.5 hours, additional phenylacetyl chloride $(0.56$ $\mathrm{ml})$ in dichloromethane $(13 \mathrm{ml})$ was added. After another 1.5 hours, starting material had been consumed and the solution was evaporated to dryness under reduced pressure. The residue was dissolved in dichloromethane and extracted with saturated $\mathrm{NaHCO}_{3}$ solution. The organic layer was dried $\left(\mathrm{Na}_{2} \mathrm{SO}_{4}\right)$, filtered and evaporated to dryness. The residue was dissolved in toluene and separated by chromatography, eluting with a linear gradient of toluene-ethyl acetate (1:1) and ethyl acetate. Early fractions containing the desired product were located by TLC, combined and evaporated to yield $0.8 \mathrm{~g}(24 \%)$ of $2^{\prime}-O$-acetyl-23,4'-di- $O$-phenylacetyl-DMT; FD-MS $1,020\left(\mathrm{M}+\mathrm{H}^{+}\right) ; \mathrm{UV} \lambda_{\max } \mathrm{nm}$ (ع) $282(18,700)$; NMR $\delta 2.08$ (s, acetyl), 3.62, $3.7\left(\mathrm{CH}_{2} \mathrm{Ph}\right), 7.3(\mathrm{~m}$, phenyl). Later fractions gave $1.1 \mathrm{~g}$ $(35 \%)$ of 2'-O-acetyl-23- $O$-phenylacetyl-DMT; FD-MS $901\left(\mathrm{M}^{+}\right)$; UV $\lambda_{\max } \mathrm{nm}(\varepsilon) 280(20,400), 204$ (14,000); NMR $\delta 2.08$ (s, acetyl), 3.62 (s, $\left.\mathrm{CH}_{2} \mathrm{Ph}\right), 7.28$ (m, phenyl).

\section{2'-O-Acetyl-23,4"-di- $O$-propionyl- and 2'-O-Acetyl-3,23,4"'tri- $O$-propionyl-DMT}

$2^{\prime}$-O-Acetyl-DMT $(2 \mathrm{~g}, 2.6 \mathrm{mmol})$ was dissolved in acetone $(40 \mathrm{ml})$ and pyridine $(8 \mathrm{ml})$ and treated with a solution of propionic anhydride $(40 \mathrm{ml})$ in acetone $(20 \mathrm{ml})$ dropwise with stirring at room temp. After stirring for 5 days, the mixture was evaporated under reduced pressure. The residual oil was dissolved in ethyl acetate and extracted with saturated $\mathrm{NaHCO}_{3}$ solution. The organic layer was dried $\left(\mathrm{Na}_{2} \mathrm{SO}_{4}\right)$, filtered and evaporated. The residue was dissolved in a small volume of toluene and separated by chromatography, eluting with a linear gradient of toluene and ethyl acetate. Fractions containing the desired products were located by TLC, combined and evaporated to yield $1.4 \mathrm{~g}(57 \%)$ of 2'-O-acetyl-3,23,4" $2^{\prime \prime}$-tri-O-propionyl-DMT; FD-MS $951\left(\mathrm{M}^{+}\right)$; UV $\lambda_{\max } \mathrm{nm}(\varepsilon) 278(22,000)$; NMR $\delta 2.06$ (s, acetyl), $1.1\left(\mathrm{~m}\right.$, three propionyl); and $0.67 \mathrm{~g}(29 \%)$ of $2^{\prime}$-O-acetyl-23,4"'-di-O-propionyl-DMT; FD-MS $895\left(\mathrm{M}^{+}\right)$; UV $\lambda_{\max } \mathrm{nm}(\varepsilon) 280(21,700)$.

2'-O-Acetyl-23-O-phenoxyacetyl-, 2-O-Acetyl-4",23-di- $O$-phenoxyacetyl- and 2'-O-Acetyl-3,23-di$O$-phenoxyacetyl-DMT

2'-O-Acetyl-DMT $(2.75 \mathrm{~g}, 3.5 \mathrm{mmol})$ was dissolved in dichloromethane $(75 \mathrm{ml})$ and pyridine $(0.8 \mathrm{ml})$ and treated with a solution of phenoxyacetyl chloride $(1.2 \mathrm{ml}, 8.8 \mathrm{mmol})$ in dichloromethane $(25 \mathrm{ml})$ dropwise with stirring at room temp. After 1 hour, the reaction mixture was poured into saturated $\mathrm{NaHCO}_{3}$ solution. The organic layer was separated, dried $\left(\mathrm{Na}_{2} \mathrm{SO}_{4}\right)$, filtered and evaporated under reduced pressure. The residual solid foam was separated by flash chromatography, eluting with toluene - ethyl acetate $(1: 1)$. Based on TLC results, fractions were combined and evaporated to dryness to give $1.5 \mathrm{~g}$ of $2^{\prime}-O$-acetyl-23- $O$-phenoxyacetyl-DMT; FD-MS $918\left(\mathrm{M}+\mathrm{H}^{+}\right)$; UV $\lambda_{\max } \mathrm{nm}$

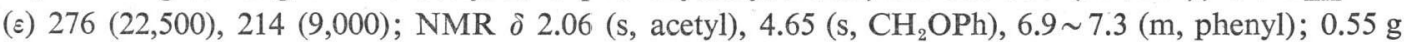
of 2'-O-acetyl-4" ,23-di- $O$-phenoxyacetyl-DMT; FD-MS 1,052 (M+H $\left.{ }^{+}\right)$; UV $\lambda_{\max } \mathrm{nm}(\varepsilon) 276(9,000)$, 216 (7,000); NMR $\delta 2.06$ (s, acetyl), 4.64, $4.7\left(\mathrm{CH}_{2} \mathrm{Ph}\right), 6.88,6.98,7.3$ (phenyl); and $0.03 \mathrm{~g}$ of $2^{\prime}-O-$ acetyl-3,23-di-O-phenoxyacetyl-DMT; FD-MS 1,052 $\left(\mathrm{M}+\mathrm{H}^{+}\right)$; UV $\lambda_{\max } \mathrm{nm}(\varepsilon) 276(11,000), 217$ (7,800); NMR $\delta 2.04$ (s, acetyl), 4.58, $4.73\left(\mathrm{CH}_{2} \mathrm{Ph}\right), 6.88,7.0,7.28$ (phenyl).

\section{3,4"-Di- $O$-phenylacetyl-DMT}

$2^{\prime}-O$-Acetyl-23,4" $4^{\prime \prime}$ di- $O$-phenylacetyl-DMT $(0.36 \mathrm{~g}, 0.36 \mathrm{mmol})$ was dissolved in $80 \%$ aq methanol $(30 \mathrm{ml})$ and refluxed for 4.5 hours. The solution was cooled to room temp and evaporated to dryness under reduced pressure to yield $0.29 \mathrm{~g} \mathrm{(84 \% )}$ of 23,4"-di- $O$-phenylacetyl-DMT; FD-MS $978\left(\mathrm{M}+\mathrm{H}^{+}\right)$; UV $\lambda_{\max } \mathrm{nm}(\varepsilon) 282(20,100) 204(\mathrm{sh}, 20,000)$; NMR $\delta 3.63,3.72$ (s, two $\left.\mathrm{CH}_{2} \mathrm{Ph}\right), 7.22 \sim 7.34$ (m, two phenyl).

\section{Trichloroacetyl Derivatives of DMT}

2'-O-Acetyl-DMT $(10 \mathrm{~g}, 12.8 \mathrm{mmol})$ was dissolved in dichloromethane $(50 \mathrm{ml})$ and pyridine $(50 \mathrm{ml})$. This solution was cooled in an ice bath and treated dropwise with a solution of trichloroacetic 
anhydride $(4 \mathrm{ml})$ in dichloromethane $(10 \mathrm{ml})$. After stirring for 2.5 hours, the solution was diluted with toluene and evaporated to dryness under reduced pressure. The residue was dissolved in dichloromethane and extracted with saturated $\mathrm{NaHCO}_{3}$ solution and then dried $\left(\mathrm{Na}_{2} \mathrm{SO}_{4}\right)$. The dried solution was filtered and evaporated and the residue, dissolved in a small volume of toluene, was separated by chromatography, eluting with a linear gradient of toluene and ethyl acetate. Fractions were analyzed by TLC and appropriate fractions were combined and evaporated under reduced pressure to yield, in order of elution: $0.78 \mathrm{~g}$ of $2^{\prime}-O$-acetyl-3,23,4"-tri- $O$-trichloroacetyl-DMT; $0.78 \mathrm{~g}$ of $2^{\prime}-O$ acetyl-23,4"'-di- $O$-trichloroacetyl-DMT; $1.07 \mathrm{~g}$ of 2'-O-acetyl-3,23-di- $O$-trichloroacetyl-DMT and $5.88 \mathrm{~g}$ of $2^{\prime}$ - $O$-acetyl-23- $O$-trichloroacetyl-DMT; FD-MS 928, $930\left(\mathrm{M}+\mathrm{H}^{+}\right) ; \mathrm{UV} \lambda_{\max } \mathrm{nm}(\varepsilon) 279$ $(23,800)$.

\section{2'-O-Acetyl-4"'-O-propionyl-23-O-trichloroacetyl-DMT}

2'-O-Acetyl-23-O-trichloroacetyl-DMT $(3.6 \mathrm{~g}, 3.9 \mathrm{mmol})$ was dissolved in acetone $(50 \mathrm{ml})$ and pyridine $(12 \mathrm{ml})$. To this solution was added a solution of propionic anhydride $(6 \mathrm{ml})$ in acetone $(10 \mathrm{ml})$. After stirring at room temp for 48 hours, the solution was diluted with toluene and evaporated under reduced pressure. The residue was dissolved in dichloromethane, extracted with saturated $\mathrm{NaHCO}_{3}$ solution and dried $\left(\mathrm{Na}_{2} \mathrm{SO}_{4}\right)$. The dried solution was filtered and evaporated and the residue was dissolved in a small volume of toluene and purified by chromatography, eluting with a linear gradient of toluene and ethyl acetate. Appropriate fractions were combined and evaporated to dryness to yield $0.21 \mathrm{~g}$ of $2^{\prime}-O$-acetyl-4"- $O$-propionyl-23- $O$-trichloroacetyl-DMT, $1.5 \mathrm{~g}$ of recovered starting material and $0.97 \mathrm{~g}$ of a mixture of the two compounds. For the title compound; FD-MS 983, $985\left(\mathrm{M}^{+}\right)$; UV $\lambda_{\max } \mathrm{nm}(\varepsilon) 279(21,000)$.

\section{$4^{\prime \prime}-O$-Propionyl-DMT}

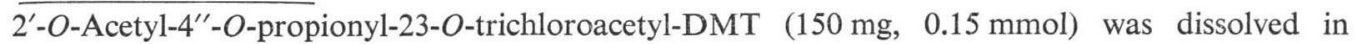
$80 \%$ aq methanol $(15 \mathrm{ml})$ and refluxed for 8 hours. The solution was cooled and evaporated under reduced pressure to give $114 \mathrm{mg}$ of $4^{\prime \prime}-O$-propionyl-DMT; FD-MS $798\left(\mathrm{M}+\mathrm{H}^{+}\right)$; UV $\lambda_{\max } \mathrm{nm}(\varepsilon) 282$ $(21,900)$.

\section{Acknowledgments}

We thank J. PASCHAL and associates for NMR spectra, J. Occolowitz and associates for mass spectra, A. Hunt and associates for UV spectra, L. TensmeYer and associates for IR spectra, L. HucksteP and R. Thomas for HPlC work, S. A. Stroy, H. Michael, M. D. Newport, P. Lubbehusen, M. E. Johnson, P. A. TARTER for technical assistance in evaluation, and G. M. WILD for helpful discussions and generous supplies of macrolide starting materials. We also thank Mrs. V. Newton for typing the manuscript.

\section{References}

1) Kirst, H. A.; G. M. Wild, R. H. Baltz, E. T. Seno, R. L. Hamill, J. W. Paschal \& D. E. Dorman: Elucidation of structure of novel macrolide antibiotics produced by mutant strains of Streptomyces fradiae. J. Antibiotics 36: 376 382, 1983

2) Okamoto, R.; K. Kiyoshima, M. Yamamoto, K. Takada, T. Ohnuki, T. Ishikura, H. Naganawa, K. TATSUta, T. TAKeUChi \& H. UmeZawa: New macrolide antibiotics produced by mutants from Streptomyces fradiae NRRL 2702. J. Antibiotics 35: 921 924, 1982

3) Okamoto, R.; M. Tsuchiya, H. Nomura, H. Iguchi, K. Kiyoshima, S. Hori, T. Inui, T. Sawa, T. TakeUCHI \& H. Umezawa: Biological properties of new acyl derivatives of tylosin. J. Antibiotics 33: 1309 1315,1980

4) Tsuchiya, M.; M. Hamada, T. Takeuchi, H. Umezawa, K. Yamamoto, H. Tanaka, K. Kiyoshima, S. MoRi \& R. Окамото: Studies of tylosin derivatives effective against macrolide-resistant strains: Synthesis and structure-activity relationships. J. Antibiotics 35: 661 672, 1982

5) Kirst, H. A.; M. Debono, J. E. Toth, B. A. Truedell, K. E. Willard, J. L. Ott, F. T. Counter, A. M. Felty-Duckworth \& R. S. Pekarek: Synthesis and antimicrobial evaluation of acyl derivatives of 16-membered macrolide antibiotics related to tylosin. J. Antibiotics 39: 1108 1122, 1986

6) NAGel, A. A. \& L. A. VinCENT: Selective cleavage of the mycinose sugar from the macrolide antibiotic tylosin: a unique glycosidic scission. J. Org. Chem. 44: 2050 2052, 1979 
7) Ōmura, S. \& H. TANAKA: Production and antimicrobial activity of macrolides. In Macrolide Antibiotics. Ed., S. OMura, pp. 12 18, Academic Press, Florida, 1984

8) Oкамото, R.; T. Fukumoto, H. Nomura, K. Kiyoshima, K. Nakamura \& A. Takamatsu: Physicochemical properties of new acyl derivatives of tylosin produced by microbial transformation. J. Antibiotics 33: 1300 1308, 1980

9) ŌMura, S.: The antibiotic cerulenin, a novel tool for biochemistry as an inhibitor of fatty acid synthesis. Bacterial Rev. 40: 681 697, 1976

10) Sadakane, N.; Y. Tanaka \& S. ŌMura: Hybrid biosynthesis of derivatives of protylonolide and M4365 by macrolide-producing microorganisms. J. Antibiotics 35: 680 687, 1982

11) Окамото, R.; T. Fukumoto, Y. Inui \& T. Takeuchi (Sanraku-Ocean): Macrolide antibiotic N-1. Jpn. Kokai 43013('80), Mar. 26, 1980

12) Sakakibara, H. \& S. ŌMURA: Chemical modification and structure-activity relationship of macrolides. In Macrolide Antibiotics. Ed., S. ŌMURA, pp. 109 119, Academic Press, Florida, 1984

13) Thomson, T. D.: Tylosin distribution in normal and pneumonic swine lung. Proc. Am. Assoc. Swine Practioners. pp. 59 64, Kansas, Mar. 4 6, 1984

14) Still, W. C.; M. Kahn \& A. Mitra: Rapid chromatographic technique for preparative separations with modest resolution. J. Org. Chem. 43: 2923 2925, 1978

15) Kirst, H. A.; G. M. Wild, R. H. Baltz, R. L. Hamill, J. L. Ott, F. T. Counter \& E. E. Ose: Structure-activity studies among 16-membered macrolide antibiotics related to tylosin. J. Antibiotics 35 : $1675 \sim 1682,1982$

16) BAltz, R. H. \& E. T. Seno: Properties of Streptomyces fradiae mutants blocked in biosynthesis of the macrolide antibiotic tylosin. Antimicrob. Agents Chemother. 20: 214 225, 1981 